\title{
Some Current Controversies in Critical Legal Studies
}

\section{Citation}

Mark Tushnet, Some Current Controversies in Critical Legal Studies, 12 Ger. L.J. 290 (2011).

\section{Published Version}

http://www.germanlawjournal.com/pdfs/Vol12-No1/

PDF_Vol_12_No_01_290-299_Articles_Tushnet.pdf

\section{Permanent link}

http://nrs.harvard.edu/urn-3:HUL.InstRepos:10880556

\section{Terms of Use}

This article was downloaded from Harvard University's DASH repository, and is made available under the terms and conditions applicable to Open Access Policy Articles, as set forth at http:// nrs.harvard.edu/urn-3:HUL.InstRepos:dash.current.terms-of-use\#OAP

\section{Share Your Story}

The Harvard community has made this article openly available.

Please share how this access benefits you. Submit a story.

Accessibility 


\title{
Articles
}

\section{Some Current Controversies in Critical Legal Studies}

\author{
By Mark Tushnet ${ }^{*}$
}

The first few years in the development of critical legal studies (CLS) saw an ongoing discussion of an issue that was framed as "rationalism v. irrationalism". ${ }^{1}$ The labels, it now appears, were misleading, for the discussion can be better understood as concerning the utility - for purposes of orienting strategic action as well as of understanding the social order - of relatively large-scale social theories in the traditions of Marx and Weber. ${ }^{2}$ The distinctive contribution of CLS to leftist social thought, and the embodiment of the fact that one side in the earlier discussion more or less prevailed, is its insistence that a leftist social and political theory does not need to be grounded in that sort of social theory.

This essay examines several positions now prevalent in CLS that seek to explicate this distinctive contribution. ${ }^{3}$ It argues that, though CLS has indeed advanced our

\footnotetext{
* J.D. and M.A. (History), Yale University, 1971; law clerk to Justice Thurgood Marshall of the United States Supreme Court; Professor of Law, University of Wisconsin, 1973-1981, Georgetown University Law Center, 1981-. Author: The American Law of Slavery, 1810-1860: Considerations of Humanity and Interest, 1981; The NAAP's Legal Strategy Against Segregated Education, 1925-1950, 1987; Red, White and Blue: A Critical Analysis of Constitutional Law, 1988; Central American and the law: The Constitution, Civil Liberties, and the Courts, 1988; co-author of two casebooks [Federal Jurisdiction: Policy and Practice (with Howard Fink), 1984 (2nd ed. 1987), Constitutional Law (with Geoffrey Stone, L. Michael Seidman, and Cass Sunstein), 1986]; numerous articles on constitutional law and history. Recent publications: Taking the Constitution Away from the Courts (Princeton University Press, 1999); Weak Courts, Strong Rights: Judicial Review and Social Welfare Rights in Comparative Perspective (Princeton University Press, 2008); Why the Constitution Matters (Yale University Press, 2010). Email: mtushnet@law.harvard.edu

${ }^{1}$ The discussion of "rationalism" and "irrationalism" never quite surfaced in those terms in the CLS literature. For a brief discussion, see Dalton, Book Review, 6 HARV. WM's L. J. 229, 231-39 (1983). This suggests that a preliminary caution about the discussion that follows is important: Any map of "positions" within CLS distorts what people actually say and think, by imposing an order to assist others who seek a general orientation to the discussions. Nonetheless, providing that sort of orientation seems useful, even if doing so does make discussions within CLS appear more orderly than they actually are.

${ }^{2}$ An alternative formulation of the subject of these discussions would be that they concerned the relative usefulness of structural and subjectivist orientations in understanding social life and providing guidance for political action.

${ }^{3}$ I regard this examination as my effort, as a participant in the first generation of CLS arguments, to come to grips with developments, refinements, deepening, and elaborations that have been provided by a second generation of CLS authors. This gives my discussion a certain distanced quality, with which I am not entirely comfortable. It should be noted as well that many people associated with CLS find that their work converges with, and is influenced by, some aspects of contemporary feminist theory. Because I am less familiar with discussions among feminist theorists, I have not attempted to do more than suggest that the map offered here may correspond to a map of feminist discussions.
} 
understanding of what leftist social thought can be, further theoretical development of the various positions examined here is likely to require re-connecting CLS to the tradition of large-scale theorizing. The argument begins by describing some criticisms of CLS, and then explains how each of the various positions demonstrates why those criticisms are misplaced. Each explanation includes a discussion of gaps that remain in the CLS enterprise.

The criticisms of CLS can best be understood by seeing them in light of the standard intellectual history of CLS. That history holds that CLS carries forward the intellectual program of the Legal Realists of the 1930s. ${ }^{4}$ For present purposes, the Realist project can be described as having two elements. The Realists insisted that statements of abstract legal doctrine had no real or cognitive content, and so could not solve any concrete cases or problems. In addition, they insisted that the only sensible way to resolve legal questions was to pay attention to, and choose among, the policies that were implicated in the questions.

Legal scholarship in the United States, including CLS, is dominated by the Realists' legacy. Thus, when CLS writers describe their complete acceptance of the first Realist proposition, about the emptiness of abstract concepts, they are met with an indifferent yawn, to the effect that "We are all Realists now" insofar as we all accept that proposition. CLS is distinctive, though, in its rejection of the second, policy-oriented proposition. Unlike other contemporary schools of legal thought in the United States, which differ only over which policies ought to be preferred, CLS argues that that entire mode of thought is mistaken.

Responses to that argument rarely engage it directly. Instead, they suggest that one could not be a serious leftist and simultaneously reject some sort of policy orientation, that is, an orientation towards promoting the policies of the working class or other objects of leftist affection. One version of the criticism comes from what might be described in conventional terms as the right of CLS - that is, from center-left liberals and center-right conservatives. ${ }^{5}$ A sympathetic version of this criticism would go along these lines: People in CLS have criticized the Realists, center-left liberals, and center-right conservatives by pointing out the inadequacies of their policy analyses. Perhaps all of that criticism is correct. Nonetheless, as leftist heirs to Legal Realism, you must be committed to the view that lawmaking is policy-choice. After all, what else can you mean when you say that all law is politics? Agreeing that law is policy-choice, you are certainly entitled to believe that the appropriate policies to pursue are more radically egalitarian than those sought in the

\footnotetext{
4 See "Round and Round the Bramble Bush": From Legal Realism to Critical Legal Scholarship, 95 HARVARD LAW REVIEW 1669 (1982). For a contrary view of the relation between CLS and Legal Realism, see Critical Legal Studies as an Anti-Positivist Phenomenon, 72 VA. L. REV. 983 (1986).

${ }^{5}$ Examples are Johnson, Do You Sincerely Want To Be Radical?, 36 STAN. L. REV. 247, center-right (1984); see also Owen Fiss, The Death of the Law?, 72 CORN. L. REV. 1 (1986).
} 
New Deal or the civil rights movement of the 1960s. However, notice that the Realists undertook the hard work of providing a coherent theoretical defense of their choices; they tried to explain why their goals were morally justified and how those goals could reasonably be achieved through the institutions they designed. If CLS writers intend to be serious about their leftist claims, they too must provide the requisite moral and social theoretical defenses; merely invoking "utopian" ideas cannot be sufficient. ${ }^{6}$

Another version of the criticism comes from people who describe themselves as to the left of $\mathrm{CLS}^{7}$ Here the criticism is that CLS, unlike classical Marxism, fails to provide a social theoretical basis for any judgments about what political action in the service of leftist goals is appropriate. It identifies no agency of historical change, and so degenerates into mere subjectivity; and it describes no processes by which its leftist goals are bound to, or even are likely to be, realized in the social order.

There is a relatively superficial sense in which these criticisms are largely correct. ${ }^{8}$ The CLS views to be examined here indeed do not offer the kinds of theoretical defenses that these criticisms say are necessary. The CLS position in response is, why are such defenses needed? What is there about a moral, political, or social theory that makes it a prerequisite for leftist political action? Indeed, it may be the primary contribution of CLS to leftist thought in general to insist than it was simply a mistake for people to have thought that such theoretical justifications were needed. ${ }^{9}$

The CLS position can be defended by reversing the burden of proof. Those who demand a theory appear to believe that political action that is not theoretically grounded is bound to fail. ${ }^{10}$ Perhaps so, but the political history of the left internationally is that political action that was theoretically grounded also invariably failed. It might be that the theoretical grounding was the wrong one. Yet, in light of this history, it is not obviously wrong for CLS writers to suggest that there simply is no connection between theoretical grounding and successful political action.

\footnotetext{
${ }^{6}$ See Fiss, supra, note 5, at 15 ("feminism ... (must) recognize the claim to sexual equality as an expression of the ideals and values we hold in common").

${ }^{7}$ For an example, see Donald Brosnan, Serious But Not Critical, 60 Southern California LaW ReVIeW 259 (1986).

${ }^{8}$ Even in this relatively superficial sense, these criticisms underestimate the degree of diversity within CLS.

${ }^{9}$ In some CLS writings, this contribution is phrased as an insistence on "pragmatism" as the proper philosophical grounding for CLS. A cogent, and to me convincing, criticism of this insistence is John Stick, Can Nihilism Be Pragmatic?, 100 HARVARD LAW REVIEW. 332 (1986). I should emphasize that the criticism is cogent only to the extent that pragmatism is offered as a foundational philosophical theory; Stick clearly knows that pragmatism is fundamentally non-foundational, and when used appropriately does link CLS to one philosophical tradition.

${ }^{10}$ Here I address only the criticism from "the left", for liberals, centrists, and rightists are not interested in providing criteria for successful leftist political action. The entire range of criticisms is, however, addressed in the map that concludes this discussion .
} 
There is, however, a problem here, and identifying it will lead to the identification of four CLS positions that seek to explain why theoretical grounding is unnecessary. It is not a forced reading of the CLS position as characterized so far that it urges people simply to take political action without worrying about having a large-scale political or moral theory to back them up. The problem is that, as presented so far, the CLS position provides no guarantees or even reasons to think that the action that people will take will be leftist rather than fascist. ${ }^{11}$ The four CLS positions described below try, in different ways, to provide such reasons. ${ }^{12}$ These positions are best considered tendencies of thought within CLS. They make sense of, and help to organize, many things that CLS writers have said. However, no single writer is committed to any fully worked-out version of any of the tendencies, and most CLS writers have said things, often within a single article, that make the most sense when understood as elements of different tendencies.

(1) Romanticism: Joseph Singer has given the most straightforward account of these reasons by offering a romantic view of human nature. Countering hard-nosed views that "what people really like is doing horrible things to each other", Singer responds sensibly that they "do not just want to be beasty to each other ... (T)hey also want not to harm others ... ". ${ }^{13}$ This account deals with the otherwise awkward fact that people today indeed do want to be beastly by attributing that desire to personality distortions produced by current social conditions. Thus, Peter Gabel relies on an optimistic Freudianism to identify the social circumstances under which "unalienated relatedness" could be realized. ${ }^{14}$ What Roberto Unger means by his version of a romantic view of human nature is less clear, but it may be significant that he too ends by presenting a program for psychiatry. ${ }^{15}$

The difficulty with the romantic view of human nature is its current implausibility. It can be made more plausible by its account of personality distortion. Yet, it may not be accidental that CLS, an intellectual enterprise located primarily in the United States, has adopted the optimistic reading of Freud, in contrast to the darker view taken by Herbert Marcuse. ${ }^{16}$ Note, too, that bolstering the romantic view by drawing on some sort of socialpsychological theory draws CLS in the direction of the large-scale theories mentioned earlier.

\footnotetext{
${ }^{11}$ For those with a historical bent, the difficulty might be suggested by invoking the political career of Benito Mussolini.

12 I should note that I am sympathetic to all four of the tendencies described in the text, but also that I present them in order of what seems to me their increasing plausibility.

${ }^{13}$ Joseph William Singer, The Player and the Cards: Nihilism and Legal Theory, 94 YALE L. J. 1, 54 (1984).

${ }^{14}$ Peter Gabel \& Duncan Kennedy, Roll Over, Beethoven, 36 STAN. L. REV. 1, 1 (1984).

${ }^{15}$ Roberto Mangabeira, Unger, Passion: An Essay on Personality, 275-300 (1984).

${ }^{16}$ Herbert Marcuse, ERos ANd Civilization: A Philosophical InQUiRy INTO FreUd, 217-51 (1955).
} 
(2) Global pragmatism: A second tendency in CLS abjures the large theoretical enterprise, preferring instead to work for programs that promise to make life a little better. This tendency, like the first, is attracted to general projects of equalization, destruction of hierarchy, and the like. Any such pragmatic program must explain why its proponents believe that their projects will make life better, and to do so it must contain some criteria for sorting the better from the worse. In this tendency, Jürgen Habermas's identification of deep-rooted human interests, his universal pragmatics, is obviously attractive. Drucilla Cornell's ongoing intellectual project seems best located in this tendency. Cornell, explicitly invoking Habermas, describes a regulative ideal of dialogic reciprocity among people who treat each other as "partners in a common enterprise" and offers a "pragmatic rendering of the ideal speech situation", while insisting that dialogue consists simultaneously of moments of negativism and affirmation. ${ }^{17}$

Habermas's project is in the tradition of philosophical anthropology, and thus is rather closely related to the romantic tendency, at least insofar as both are interested in discovering fundamental aspects of human nature. Cornell disclaims the objectivism of that tradition. Yet, to the extent that she defends dialogic reciprocity as positive, she may be invoking elements of that tradition, despite her acute awareness of its defects. In any event, once again, the linkage to modern versions of large-scale theories is obvious.

(3) Local pragmatism: The third tendency in CLS is a much more modest pragmatism. Purely political, it makes no claims about what "people in general" will or ought to do. Rather, it takes as a given that people associated with CLS, and their potential political allies, are interested from the start in a (somewhat) more egalitarian society, and in eliminating (or reducing the prevalence of) illegitimate hierarchy. The theoretical demand is for some basis for distinguishing between legitimate and illegitimate hierarchy, but for the pragmatic purposes of this tendency, there is no need to do so. This tendency speaks to people who already have a certain kind of experience - the experience of being oppressed - and seeks to mobilize these people politically by providing a location in which it is taken for granted that they have had that experience, and should no longer.

Gary Peller's analysis of the reification of consent in the law of rape provides a useful example. In a standard CLS analysis, invoking the first Realist proposition, Peller argues that the abstract concept of consent can be applied in particular settings only by "construct(ing) the context which is supposed to provide the ground for representing the event". He aims at demonstrating that consent in the law of rape projects "the ideological message ... that consensual sexuality is consistent with make domination in society". ${ }^{18}$ Those who demand theoretical grounding point out that the same analysis could be used to explain the

\footnotetext{
${ }^{17}$ Drucilla Cornell, Toward a Modern/Post-Modern Reconstruction of Ethics, 133 U. PA. L. REV. 291, 298, 365-72 (1985).

${ }^{18}$ Gary Peller, The Metaphysics of American Law, 73 CAL. L. REV. 1151, 1187-91 (1985).
} 
assessment, suggested for example by Norman Mailer, that female domination requires men to engage in sexual behavior that society then constructs to be coercive. They point out that the technologies of deconstruction cannot by themselves support the political conclusions implicit in the use of terms like "domination" or "illegitimate" as applied to particular arrangements.

The local pragmatist tendency in CLS in effect responds by saying that it is unconcerned, at least at this point in the argument, about convincing those for whom the terms "domination" and "illegitimate" seem misplaced, or even those who want some theoretical explanation. It is a pragmatism rooted in shared judgments within CLS about domination and justice, and aimed at those who also share, or who almost already share, those judgments. This tendency does not claim that people who have the experience of being oppressed will inevitably turn to the left. It does rely on a present-day political judgment that, given its adherents' political commitments and given the audiences to which they are directing their political efforts, they will strengthen the left by what they are doing. Frances Olsen's examination of historical patterns of "false equality" and "false paternalism" illustrates how this sort of contextual or local judgment can support present-day political positions, in Olsen's case support for a particular type of benefits for working women in the face of alternative feminist arguments against provision of that type of benefit. ${ }^{19}$ The criticism from the left, described earlier, says that these CLS adherents should direct their political energies elsewhere, to more promising agents of historical change. Yet, in light of who CLS people are, that criticism seems unlikely to survive a proper allocation of the burden of proof.

It should go without saying that the political judgment implicit in local pragmatism could turn out to be mistaken. The critics from the left might be correct in their claim that CLS diverts leftists from more productive political activities or even that CLS weakens the left. More substantially, the political judgment might be wrong in its assessment of how widespread the experience of oppression is, in which case CLS will simply lose the political battle it has started. One point to stress, however, is that this kind of pragmatism, localized in the experience of the audiences for CLS, does indeed generate concrete proposals for change. The proposals range from Duncan Kennedy's utopian outline of a counterhegemonic law school, to William Simon's suggestion that a certain proportion of decisions by welfare agencies be reviewed automatically. ${ }^{20}$ These proposals are not justified by any large-scale theory. Like Olsen's, they result from an assessment of the politics of the places

\footnotetext{
${ }^{19}$ Frances Olsen, From False Paternalism to False Equality: Judicial Assaults on Feminist Community, Illinois 1869 1895, $84 \mathrm{MICH}$. L. REV. 1518, 1541 (1986). This position seems to be common ground in feminist discussions of such issues as the regulation of pornography and, as Olsen indicates, maternity/paternity/parental leave for workers.

20 Duncan Kennedy, Legal Education and the Reproduction of Hierarchy (1982); William H. Simon, Legality, Bureaucracy, and Class in the Welfare System, 92 YALE L. J. 1198, 1267-68 (1983).
} 
in which CLS people find themselves - in law schools, as legal activists in particular fields, and the like - and from judgments about what sorts of proposals, made in those environments, are likely to contribute to building a leftist movement. ${ }^{21}$ Like the romantic tendency, the local pragmatic tendency must have some sense of how localized proposals have transformative potential, how, that is, people embedded in contexts of oppression can find in their experiences the resources for change. One line of thought develops one way of utilizing the first Realist proposition. Abstract legal concepts are taken apart to show how each contains or expresses paired oppositions, or contradictions. That line of thought argues that standard legal analysis reproduces oppression by valuing one side of the contradiction. Elevating the suppressed or devalued side has transformative potential, it argues, because the suppressed value, which is an aspect of what makes experience seem oppressive, is implicit in what is already valued by the oppressive culture. The reversal of valuation brings to the fore one dimension of what oppression had suppressed. $^{22}$

A second line of thought draws on another aspect of Legal Realism, as yet undiscussed here. The Realists' orientation towards policy-choice made them receptive to the claim of social science, for, they thought, if they were concerned about the actual implementation of policy in the "real world", they had to understand how the "real world" actually worked. Social science promised to inform them about that. Similarly, pragmatic judgments must be informed by social understanding, not all of which can simply be absorbed by a participant immersed in a situation. The socio-legal research associated with the Law and Society Association often provides the model for the kind of social understanding that is useful in informing such pragmatic judgments. ${ }^{23}$

The antitheoretical impulse behind the local pragmatic tendency does conceal one important issue. CLS leftists are assumed to be able to identify, not just their own, but other peoples' experiences of being oppressed, so that they can determine what sorts of appeals are likely to be politically effective for their audiences. Yet, the account so far provides no reasons for thinking that they can get this project started. For all that appears, CLS leftists could be projecting their own disturbances onto others who do not actually

\footnotetext{
${ }^{21}$ It is possible, but not necessary, to take this sort of contextualized judgment as the model offered by this tendency for all legal decision-making. It is not necessary to do so because the emphasis within this tendency on the importance of context means that it is difficult to project a model of appropriate action very far beyond the immediate horizon.

22 I understand the invocation of ideas like the "dangerous supplement" to perform this revaluation. See Clare Dalton, An Essay on the Deconstruction of Contract Doctrine, 94 YALE L. J. 997, 1007 (1985); Gerald Frug, The Ideology of Bureaucracy in American Law, 97 HARV. L. REV. 1276, 1288 (1984).

${ }^{23}$ See Michael Trubek, Where the Action is: Critical Legal Studies and Empiricism, 36 STANFORD LAW REVIEW 575 (1984); William Whitford, Lowered Horizons: Implementation Research in a Post-CLS World, WISCONSIN LAW REVIEW 755 (1986).
} 
experience life as oppressive. One obvious explanation for one's ability to identify oppression begins by seeing oppression not as an experience but as a social circumstance. According to this explanation, we can find out who shares our oppression by examining the social circumstances in which we find ourselves and then by assuming that those who find themselves in similar circumstances have similar experiences of being oppressed - or, more dramatically, by defining as oppression, being in the appropriate circumstances. Were local pragmatism to develop along these lines, it would reunite with classical social theory, whose project can be taken to be, for present purposes, precisely the identification of those social circumstances that contribute to oppression.

The anti-theoretical impulse in local pragmatism tends to supply a different account. It appeals to an apparently simple existential fact, that the experience of oppression is, qua experience, shared. Yet, this existential appeal conceals issues that, in my judgment, have not been adequately addressed by CLS. The issues can be derived from the implications of Duncan Kennedy's term "intersubjective zap". ${ }^{24}$ The "zap" refers to an existential experience that cannot be captured in the words of the discourse typical of classical social theory. The difficulties derive from "intersubjective". The term obviously claims that the unarticulable experiences are shared, yet it is unclear how that claim can be supported. On the surface, it would seem that the inability to articulate what the experiences are means that they are private in the sense used in discussion of Wittgenstein's "private language" argument. If that understanding is correct, the experiences cannot be shared. ${ }^{25}$ Some theorization of the intersubjective dimension of intersubjective zap seems essential if the project of local pragmatism is to succeed.

Local pragmatism has a lot going for it, which suggests that future developments in CLS may well address, directly or indirectly, the question of giving an account of intersubjectivity. It might indeed happen that his account would be a form of classical social theory, thus reintegrating tendencies that have become somewhat separate in CLS.

(4) Oppositionism: All of the tendencies described above envision what might be called an end to politics, in two senses. Their programmatic suggestions describe goals to be sought through political action and, as I have suggested, often cluster around ideas of decentralization and equality in the distribution of material goods. These are the ends of politics. The preceding tendencies also suggest that decentralization and equality are the end of politics as well, in the sense that their accomplishment would eliminate the necessity for continuing political action. Similarly, the reversal of values implicit in legal concepts often suggests that promoting the previously-suppressed value is the final goal of

\footnotetext{
${ }^{24}$ See GABEL \& KENNEDY, supra, note 14 , at 4.

${ }^{25}$ Another version of this point is that it would seem necessary to provide some explanation of why the experiences, even if shared in some sense, should be characterized as (joint, intersubjective) experiences of oppression.
} 
politics. $^{26}$ Though I do not wish to overstate this point, it does seem that these overall political commitments are, according to their adherents, what make the preceding tendencies leftist.

By envisioning an end to politics, however, the preceding tendencies relinquish the claim that the contradictions they find in contemporary law are in any useful sense fundamental. The fourth tendency in CLS retains that claim, and relinquishes instead the assumption that CLS necessarily has a leftist commitment. Seeing contradiction as fundamental, and believing that the risk of illegitimate hierarchy will almost certainly be realized in any future society, this tendency appropriates some elements in theories of deconstruction. ${ }^{27}$ It insists that the appropriate stance is one of opposition to whatever the existing order is, precisely in order to assure that no illegitimate hierarchy will ever congeal. Roberto Unger captures this dimension of the fourth tendency in his description of destabilization rights, "claims to the disruption of established institutions ... that have ... contributed to the very kind of crystallized plan of social hierarchy and division that the entire constitution wants to avoid. ${ }^{28}$ As it happens, taking an oppositional stance today means being on the left, as defined in conventional political terms. But opposition is what matters: In a socialist society, the critical legal scholar would criticize socialism as denying the importance of individual achievement, decentralization as an impediment to material and spiritual achievement, and the like.

Unger has suggested that the oppositional stance is impossible to sustain psychologically and, I would add, perhaps politically. As a matter of political strategy, it may be impossible to develop a political movement at whose base lies mere oppositionism: Some vision of a better future, of the sort offered by the first three tendencies, may be necessary for effective political action. If so, the very existence of a variety of tendencies within CLS may be what can sustain the oppositional one. By pointing out that they identify themselves

\footnotetext{
${ }^{26}$ Conversations have convinced me that people often misread such works as Duncan Kennedy, Form and Substance in Private Law Adjudication, 89 HARV. L. REV. 1685 (1976), and Duncan Kennedy, Distributive and Paternalist Motives in Contract and Tort Law, with Special Reference to Compulsory Terms and Equal Bargaining Power, 41 MD. L. REV. 563 (1982), to provide policy-oriented suggestions that the law would be straightened out permanently if we made altruism and paternalism the primary values promoted by law. Such conversations indicate that the revaluation suggested by works in the local pragmatic tendency can be taken as offering an end to politics in the senses described in the text.

The statement in the text about the "fundamental" nature of contradiction might seem to contradict Kennedy's "renunciation" of "the fundamental contradiction", in GABEL \& KENNEDY, supra, note 14, at 15. Although the renunciation can be read in other ways, I take it to be a locally pragmatic judgment that the term had become reified and was no longer functioning to sustain or generate an oppositional politics, rather than a statement about ontology or philosophical anthropology.

${ }^{27}$ See, e.g., David Kennedy, The Turn to Interpretation, 58 So. CAL. L. REV. 251 (1985).

${ }^{28}$ Robert Mangabeira Unger, The Critical Legal Studies Movement, 96 HARV. L. ReV. 561, 600, $611-15$ (1983).
} 
with the "Critical Legal Studies Movement", ${ }^{29}$ adherents of the fourth tendency demonstrate that oppositionism can be allied with, although it may not itself generate, the necessary political vision. ${ }^{30}$ More troubling is the psychological point that oppositionism is, simply, not healthy. Perhaps, however, the same mechanisms of political alliance operate internally as well: The oppositionist need not experience herself as being merely negative because she is engaged in a practical politics of opposition. He surely did not intend it in this way, but perhaps Gramsci can be read as offering a reply to Unger: "Pessimism of the intellect, optimism of the will".

\footnotetext{
${ }^{29}$ In this sense, the significance of UNGER, supra, note 28 , lies as much (or almost as much) in its title as in any of its particular arguments.

${ }^{30}$ Plainly, sustaining this sort of alliance may call for some rather difficult political action within the CLS movement, but there is no reason to think that an alliance among the tendencies cannot be sustained with some effort.
} 